\title{
Enhanced Neuroprotective Effects of Co-Administration of G-CSF with Simvastatin on Intracerebral Hemorrhage in Rats
}

\author{
Suçanlarda Intraserebral Kanama için G-CSF ile Simvastatinin Birlikte \\ Uygulanmasmmn Artmuş Nöroprotektif Etkisi
}

\author{
Xiaohe GUO, Xingyao BU, Jindou JIANG, Peixun CHENG, Zhaoyue YAN \\ Henan Provincial People's Hospital, Department of Neurosurgery, Zhengzhou, China
}

Correspondence address: Xingyao BU / E-mail: buxingyao@126.com

\begin{abstract}
AIM: Based on the neuroprotective effect of either G-CSF or statins in various neurological disease models, the purpose of this study was to evaluate the superiority of combined therapy G-CSF with simvastatin in experimental intracerebral hemorrhage (ICH).

MATERIAL and METHODS: Primary ICH was induced in male Sprague Dawley rats. G-CSF $(50 \mu \mathrm{g} / \mathrm{kg})$, simvastatin (2 mg/kg), combined G-CSF and simvastatin, or phosphate buffered saline was given at 24 hours post-ICH. Neurobehavioral outcomes were assessed in all rats. The pathological changes of neuronal ultrastructure were examined with transmission electron microscopy at the given time. Simultaneously, immunohistochemical labeling and TUNEL assay were performed.

RESULTS: Co-administration of G-CSF with simvastatin significantly promoted functional recovery and expedited the recovery time. Transmission electron microscopy revealed that combination treatment significantly improved ultrastructural outcomes. Histological examination showed that the expressions of Brdu co-labeled with NSE and GFAP, Factor VIII were higher in combined treatment than in control group. Additionally, the number of cell apoptosis was higher in control group than in experimental groups and lowest in combination group. CONCLUSION: Our results indicated that combination treatment of stroke with G-CSF and simvastatin augments the neuroprotective effect in rats after $\mathrm{ICH}$.
\end{abstract}

KEYWORDS: Hematoma, Granulocyte-colony stimulating factor, Simvastatin, Rat

öz

AMAÇ: Çeşitli nörolojik hastalık modellerinde G-CSF veya statinlerin nöroprotektif etkisi temelinde bu çalışmanın amacı deneysel intraserebral kanamada $(\mathrm{ICH})$ kombine G-CSF ve simvastatin tedavisinin üstünlüğünü değerlendirmekti.

YÖNTEM ve GEREÇLER: Erkek Sprague Dawley Sıçanlarında primer intraserebral kanama (ICH) indüklendi. ICH'den 24 saat sonra G-CSF $(50 \mu \mathrm{g} / \mathrm{kg})$, simvastatin $(2 \mathrm{mg} / \mathrm{kg})$, kombine G-CSF ve simvastatin veya fosfat tamponlu salin verildi. Nörodavranışsal sonuçlar tüm sıçanlarda değerlendirildi. Nöronal alt yapıdaki patolojik değişiklikler belirtilen sürede transmisyon elektron mikroskopisiyle incelendi. Aynı zamanda immünohistokimyasal etiketleme ve TUNEL testi yapıldı.

BULGULAR: G-CSF'nin simvastatinle birlikte uygulanması işlevsel iyileşmeyi önemli ölçüde arttırdı ve iyileşme süresini kısalttı. Transmisyon elektron mikroskopisi kombinasyon tedavisinin ultrayapısal sonuçlarda önemli bir düzelme oluşturduğunu gösterdi. Histolojik incelemeler NSE ve GFAP, Faktör VIII ile etiketlenmiş Brdu ekspresyonlarının kombine tedavi grubunda kontrol grubundan daha yüksek olduğunu gösterdi. Ayrıca hücre apopitozu sayısı kontrol grubunda deneysel gruplardan yüksekti ve kombinasyon grubunda en düşüktü.

SONUÇ: Sonuçlarımız inmenin G-CSF ve simvastatin ile kombinasyon tedavisinin sıçanlarda ICH sonrasında nöroprotektif etkiyi güçlendirdiğine işaret etmektedir.

ANAHTAR SÖZCÜKLER: Hematom, Granülosit koloni stimülasyon faktörü, Simvastatin, Sıçan

\section{INTRODUCTION}

Spontaneous intracerebral hemorrhage $(\mathrm{ICH})$ is by far the most destructive form of stroke that accounts for $10-15 \%$ of all stroke types and results in at least 30\% mortality and long-term significant disability in survivors (12). Despite the advances occurred in the surgical and medical treatment, the clinical outcome of $\mathrm{ICH}$ has failed to demonstrate the very satisfactory improvement over recent decades (1).

Granulocyte colony-stimulating factor (G-CSF) belongs to a family of cytokines that is primarily defined as a hematopoietic growth factor that induces proliferation, survival, and differentiation of neutrophil lineage cells (17). 
There is growing a body of evidence that administration of G-CSF exerts neuroprotective abilities in stroke $(10,12)$. Additionally, G-CSF itself possesses the protective effects through other mechanisms, including inhibition of apoptosis, and anti-inflammatory effects $(10,16)$.

Statins, 3-hydroxy-3-methyl-glutaryl-coenzyme A (HMG-CoA) reductase inhibitors, have actions far beyond their cholesterollowering effects. Previous reports have documented that simvastatin mediates many biological effects, such as increased nitric oxide bioavailability, improvement of endothelial function, and reduction of vascular inflammation and superoxide free radicals $(7,19)$. Recent studies suggest that simvastatin could have important protective potency in central nervous and vascular systems (8).

In virtue of the beneficial effects of both G-CSF and simvastatin on central nervous system, this study was designed to evaluate the hypothesis that G-CSF administration in combination with simvastatin may have synergistic beneficial effects on histological and neurological recovery in rats of $\mathrm{ICH}$.

\section{MATERIAL and METHODS}

All experimental procedures were performed in accordance with the National Institutes of Health Guide for the Care and Use of Laboratory animals (NIH Publication No. 8023, revised 1978). Male Sprague Dawley rats (weight 200-220 g, 4 months old) were housed in a room at $23 \pm 2{ }^{\circ} \mathrm{C}, 45 \%$ to $55 \%$ humidity with a fixed 12-h artificial light period and allowed to eat and drink ad libitum. All rats were injected i.p. with Brdu $(50 \mathrm{mg} /$ $\mathrm{kg}$, Sigma) daily for 10 consecutive days before the ICH.

\section{Stroke Model and Neurological Examination}

All rats were anesthetized by chloral hydrate (35 mg/kg i.p.), and primary $\mathrm{ICH}$ was produced by the stereotaxic infusion of $100 \mu \mathrm{L}$ of fresh (nonheparinized) autologous whole blood into the right hemisphere striatum adjacent to the subventricular zone (SVZ), with a constant infusion rate of $10 \mu \mathrm{L} / \mathrm{min}$ (15). At 24 hours post- $\mathrm{ICH}$, the rats were randomly divided into 4 groups (10 rats/group): Group 1 received recombinant human

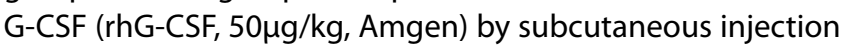
(14); Group 2 received simvastatin (8) (2 mg/kg, Sigma) by oral gavage; Group 3 received rhG-CSF $(50 \mu \mathrm{g} / \mathrm{kg}$, Amgen, subcutaneous injection) plus simvastatin ( $2 \mathrm{mg} / \mathrm{kg}$, Sigma, oral gavage); and group 4 (control group) received phosphate buffered saline (PBS). Each treatment was given starting 24 hours after ICH and continued daily for the next 7 days.

Neurological examination was performed using the modified neurological severity score (mNSS) $(2,20)$ and the cornering test $(2,20)$ which were performed before ICH and at 1, 7, 14, 21 and 28 days after $\mathrm{ICH}$ by researchers who were blinded to the treatment group.

\section{Ultrastructural examination}

For ultrastructural analysis, the animals were deeply anesthetized by an overdose of chloral hydrate, and sacrificed at 1 and 7 days after surgery ( $n=2$ rats/group). Fresh brain tissue in the perihematomal zone was carefully removed and immediately fixed in $2.5 \%$ glutaraldehyde for 24 hours at $4^{\circ} \mathrm{C}$. Semithin sections were acquired as previously described (13), double stained with uranyl acetate and lead citrate and examined using a transmission electron microscope (TEM; JEM 1400 EX; Jeol, Tokyo, Japan). For each sample, 100 each of the synapse and mitochondria were counted, measured and analyzed by three-dimensional metrology.

\section{Immunohistochemistry}

At the 2-week post- $\mathrm{ICH}$, the rats were perfused transcardially with 4\% paraformaldehyde in PBS under anesthesia ( $n=6$ rats/ group). The brains were removed from the skulls, post-fixed in $4 \%$ paraformaldehyde, sectioned into 2-mm-thick coronal through the entire region of $\mathrm{ICH}$, and then embedded in paraffin. A series of $5-\mu \mathrm{m}$ thick slices at various levels was cut from each block.

To identify the new cell formation in the neuronal and glial lineages postoperatively, double immunofluorescence labeling for 5-Bromo-2'-deoxyuridine ( Brdu, a marker for proliferation cells anti-Brdu-FITC (fluorescein isothiocyanate), 1:400; Santa Cruz) with neuron-specific enolase (NSE, a marker of mature neurons, anti-NSE-Cy3, 1:400; DAKO), and Brdu with glial fibrillary acidic protein (GFAP, a marker of astrocytes, anti-GFAP-Cy3, 1:400; DAKO) were performed. The paraffined brain sections were infiltrated in xylene followed by alcohol hydration. After undergoing antigen retrieval, each coronal section was blocked in a Tris-buffered saline containing 1\% bovine serum albumin (BSA). The slides were then incubated with primary anti- Brdu antibody. After brief washing in PBS buffer, the cerebral sections were incubated with anti-NSE or anti-GFAP. Double immunofluorescent images were acquired using fluorescent microscopy (Axiophot2, HB0100 W/2, Carl Zeiss Microlmaging Inc.) with a digital camera (C4742-95, Hamamatsu). The percentages of BrdU-NSE and BrdU-GFAP positive cells of each group were counted in 5 random microscopic fields $(400 \times)$.

To test the microvessels around the injured region, antibody against Factor VIII (dilution, 1:300, lab vision, Fremont, CA) immunostaining was performed. In brief, the slides were treated with 3\% hydrogen peroxide in methanol to block endogenous peroxidase activity. After PBS washing, sections were then incubated with antibodies against Factor VIII (dilution, 1:300, lab vision, Fremont, CA) at $4^{\circ} \mathrm{C}$ overnight. Then the sections were visualized by the avidin-biotin-peroxidase complex method and developed in diaminobenzidine (DAB). The numbers of factor VIII-positive blood vessels around the injured site were counted in three randomly chosen high power fields ( $\times 400 ; 1 \mathrm{~mm} 2$ fields).

\section{Apoptosis assay}

Additional adjacent slices were used for terminal deoxynucleotidyl transferase dUTP nick end labeling (TUNEL) assay. For each animal, apoptotic cells were analyzed by an in situ Cell Death Detection Kit, AP (Roche) following the procedure specified by the manufacturer. The percentage of 
TUNEL-positive cells was counted under a light microscope (Axioskop; Zeiss, Oberkochen, Germany) at least three randomly chosen high-power fields (HPFs) $(\times 400)$ within the region adjacent to the hemorrhagic core and averaged for each specimen.

\section{Statistical analysis}

All measurements were performed by investigator blinded to the experimental procedure. Data are reported as means \pm standard errors. Inter-group differences were analyzed using one-way ANOVA. Statistical calculations were carried out using the SPSS software (version 13.0; SPSS Inc., Chicago, IL, USA). P values less than 0.05 were considered statistically significant.

\section{RESULTS}

\section{Neurological Examination}

As evaluated by both mNSS and corner turn tests, there were no apparent differences among all four groups at 1 day after $\mathrm{ICH}$ (Figure 1A, B). The mNSS scores for G-CSF or Simvastatin monotherapy group improved at 1 week and significantly at 2,3, and 4 weeks post-ICH compared to control group (all $\mathrm{P}<0.05)$, and further improved for combined therapy with G-CSF and Simvastatin (all $\mathrm{P}<0.05$; Figure 1A). Cornering scores also showed that combination treatment significantly improved neurological function over control group from 1 week to 4 weeks (all $\mathrm{P}<0.05$; Figure $1 \mathrm{~B}$ ). It appears that co- administration of G-CSF with simvastatin group exhibited obvious improvement than either monotherapy which expedited the recovery phase.

\section{Ultrastructural Findings}

A series of ultrastructural damage of neurons were apparently observed in the area around the local hematoma, including formation of nucleolus condensed, moderate mitochondrial swelling, and destruction of synapse at day 1 post- $\mathrm{ICH}$ (Figure 2A). For the control group, extended ultrastructural damage was seen (Figure 2B). The pathologic change of cell ultrastructure in the experimental groups ameliorated obviously with the extending of time (Figure 2C,D,E).

The result of the amount of synaptic vesicle $V v$, mitochondria $\mathrm{V} v$, and mitochondria $\delta \mathrm{m}$ demonstrated that there was no significant difference between experimental groups and control group at 1 day post-ICH ( $>>0.05$; Table I). On the 7 th day, it was found that these parameters referred above decreased in control group, but increased in G-CSF and Simvastatin treatment group, especially in combination group. A statistically significant difference was found between the combination group and control groups $(P<0.05$; Table II).

\section{Neurogenesis in the Hemorrhagic Brains}

Double immunofluorescence staining for BrdU and cellspecific markers was also performed to detect any newly formed cells. Co-staining for BrdU-NSE and BrdU-GFAP
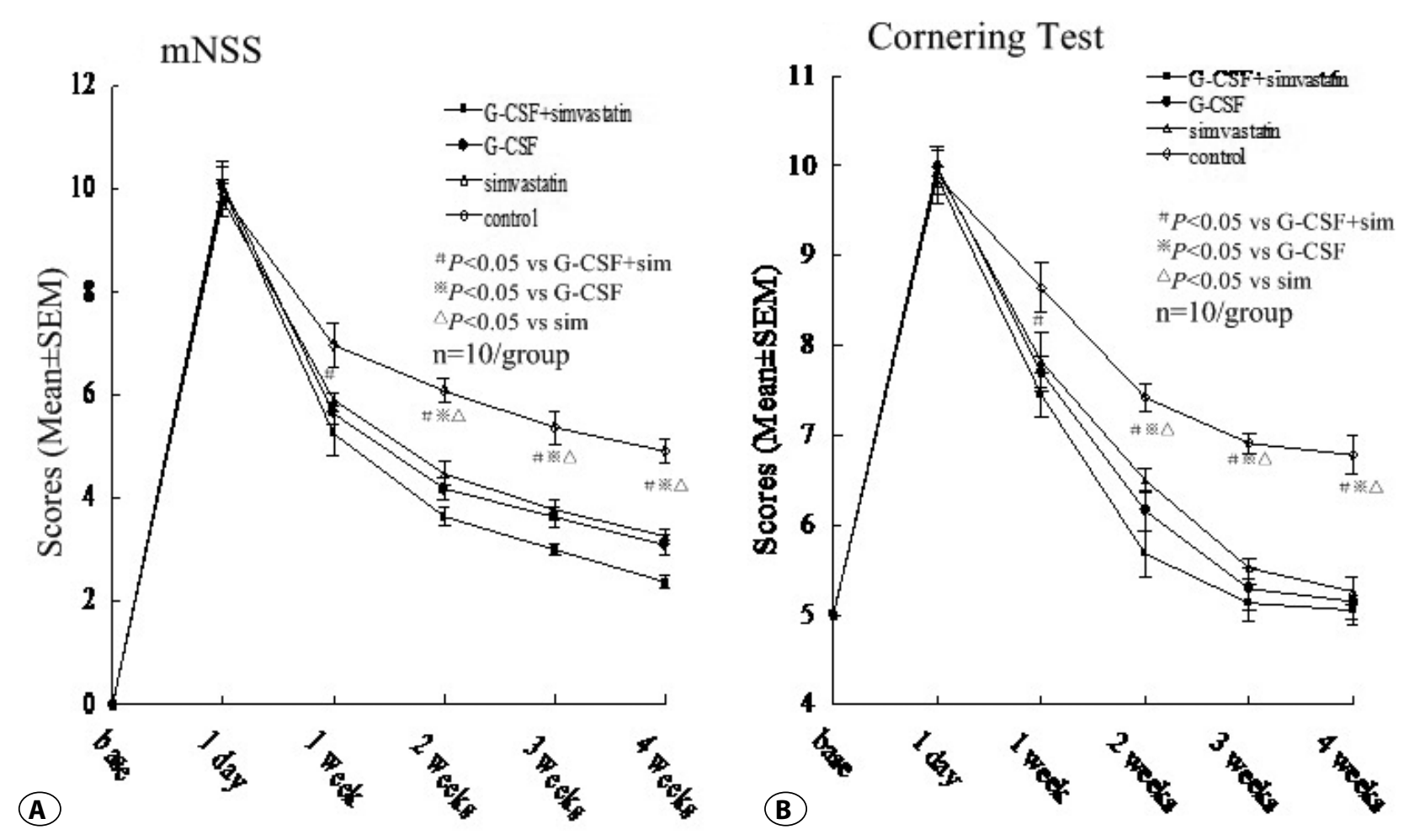

Figure 1: The results of the cornering test $(\mathbf{A})$ and $\mathrm{mNSS}(\mathbf{B})$ at baseline, days 1, 7, 14, 28 post-ICH. 
identified a subpopulation of cells that express neuronal markers while still dividing, suggesting that the cells positive for mature neuron and astrocyte markers in the vicinity of the hematoma are newly formed during the recovery stage (Figure 3). Consistent with the neurological function results, the combination group significantly increased the number of double-positive cells compared with G-CSF or Simvastatin monotherapy $(P<0.05$; Figure $3 E, J)$.

\section{Factor VIIl expression in the Hemorrhagic Brains}

As shown in Figure 4A-E, the microvasculature densities (MVD) in the combination treatment were increased significantly compared to PBS-treated group at 2 weeks after $\mathrm{ICH}$. Moreover, G-CSF or Simvastatin-treated group significantly enhanced the density of factor VIII -positive microvessels in set areas than that of the PBS-treated group. The results
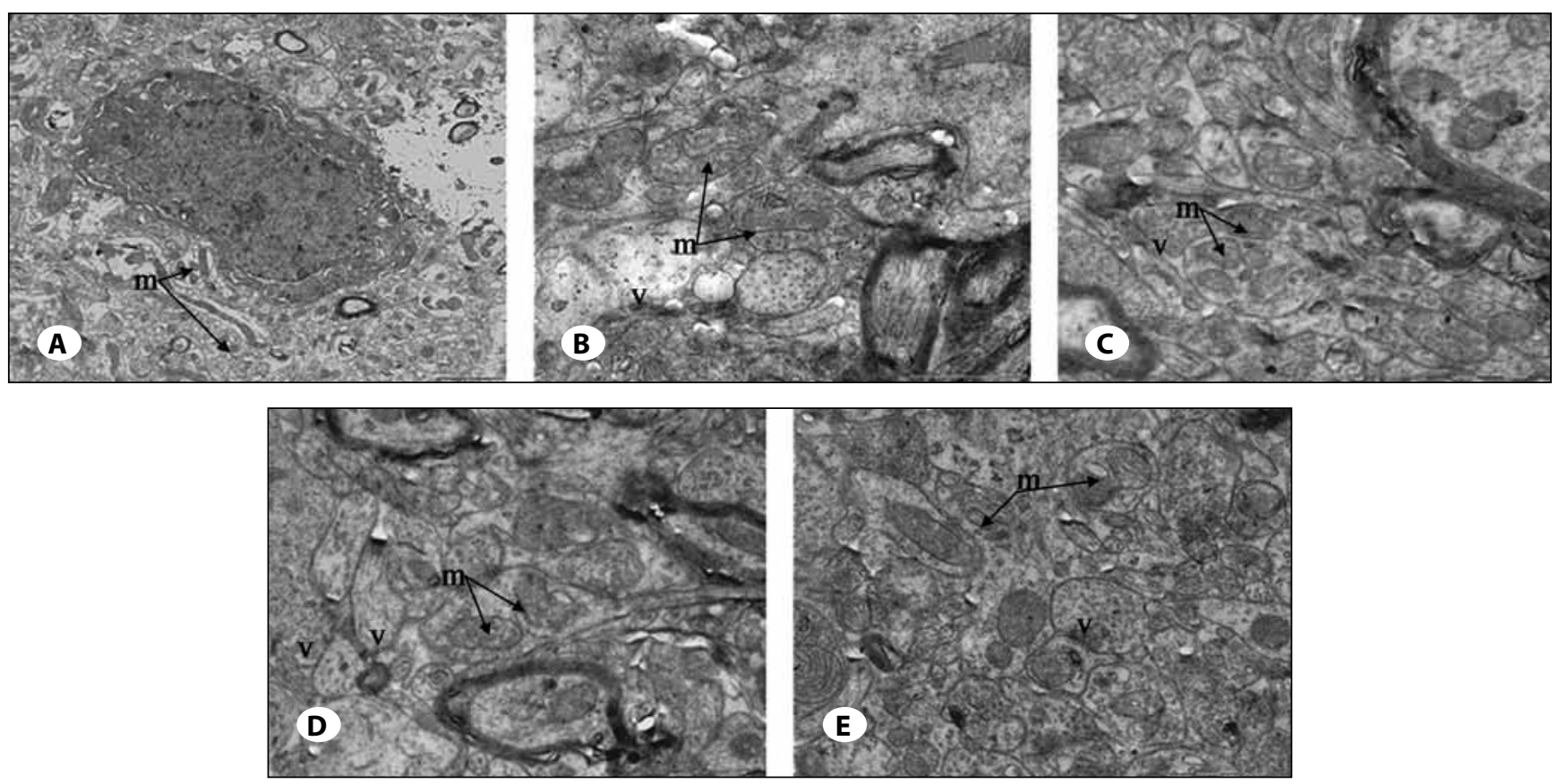

Figure 2: Representative Transmission electron micrographs of sections in the ICH border zone. A) 1 day after ICH, nucleus of neuron was condensed with normal mitochondria, mildly swollen mitochondria and myelin separation. Bar $=2$ um, $\times 8000$. $\mathrm{m}=\mathrm{mitochondrion;}$ v = vacuole. B-E) 7 days after ICH: (B) control group, part of synaptic junctions were disrupted with mitochondrial swelling, the structure of vacuoles was disrupted; (C) G-CSF, the damage was attenuated with higher synaptic vesicles; (D) Simvastatin, the damage was attenuated with higher synaptic vesicles; (E) combination treatment, the damage was notably attenuated with abundant synaptic vesicles). Bar $=1 \mathrm{um}, \times 30 \mathrm{k}$.

Table I: Mean Amount for Each Ultrastructural Feature

\begin{tabular}{|l|c|c|c|c|}
\hline Feature & Control & Simvastatin & G-CSF & Simvastatin+G-CSF \\
\hline synaptic vesicle $\mathrm{Vv}^{\dagger}$ & $14.84 \pm 2.93$ & $14.24 \pm 2.29$ & $14.78 \pm 1.92$ & $14.75 \pm 1.58$ \\
\hline mitochondria $\mathrm{Vv}^{\dagger}$ & $11.92 \pm 5.01$ & $11.85 \pm 5.01$ & $11.79 \pm 5.01$ & $11.90 \pm 5.01$ \\
\hline mitochondria $\delta \mathrm{m}^{\dagger}$ & $45.62 \pm 3.66$ & $44.86 \pm 5.02$ & $46.72 \pm 3.12$ & $45.24 \pm 4.04$
\end{tabular}

Values are means \pm standard deviation.

$\mathbf{G}-\mathbf{C S F}=$ granulocyte-colony stimulating factor.

${ }^{+}$No significant difference between any group (all $P>0.05$ ).

Table II: Mean Amount for Each Ultrastructural Feature

\begin{tabular}{|l|c|c|c|c|}
\hline Feature & Control & Simvastatin & G-CSF & Simvastatin+G-CSF \\
\hline synaptic vesicle $\mathrm{Vv}^{\dagger}$ & $7.80 \pm 1.00$ & $32.24 \pm 2.90$ & $34.28 \pm 2.35$ & $39.28 \pm 3.32$ \\
\hline mitochondria $\mathrm{Vv}^{\dagger}$ & $4.96 \pm 1.60$ & $30.79 \pm 3.01$ & $36.48 \pm 2.98$ & $39.26 \pm 3.58$ \\
\hline mitochondria $\delta \mathrm{m}^{\dagger}$ & $20.47 \pm 2.37$ & $75.80 \pm 5.82$ & $90.69 \pm 9.09$ & $128.24 \pm 9.86$
\end{tabular}

Values are means \pm standard deviation.

$\mathbf{G}-\mathbf{C S} \boldsymbol{F}=$ granulocyte-colony stimulating factor.

tSignificant difference between experimental groups and control group (all $P<0.05$ ). 


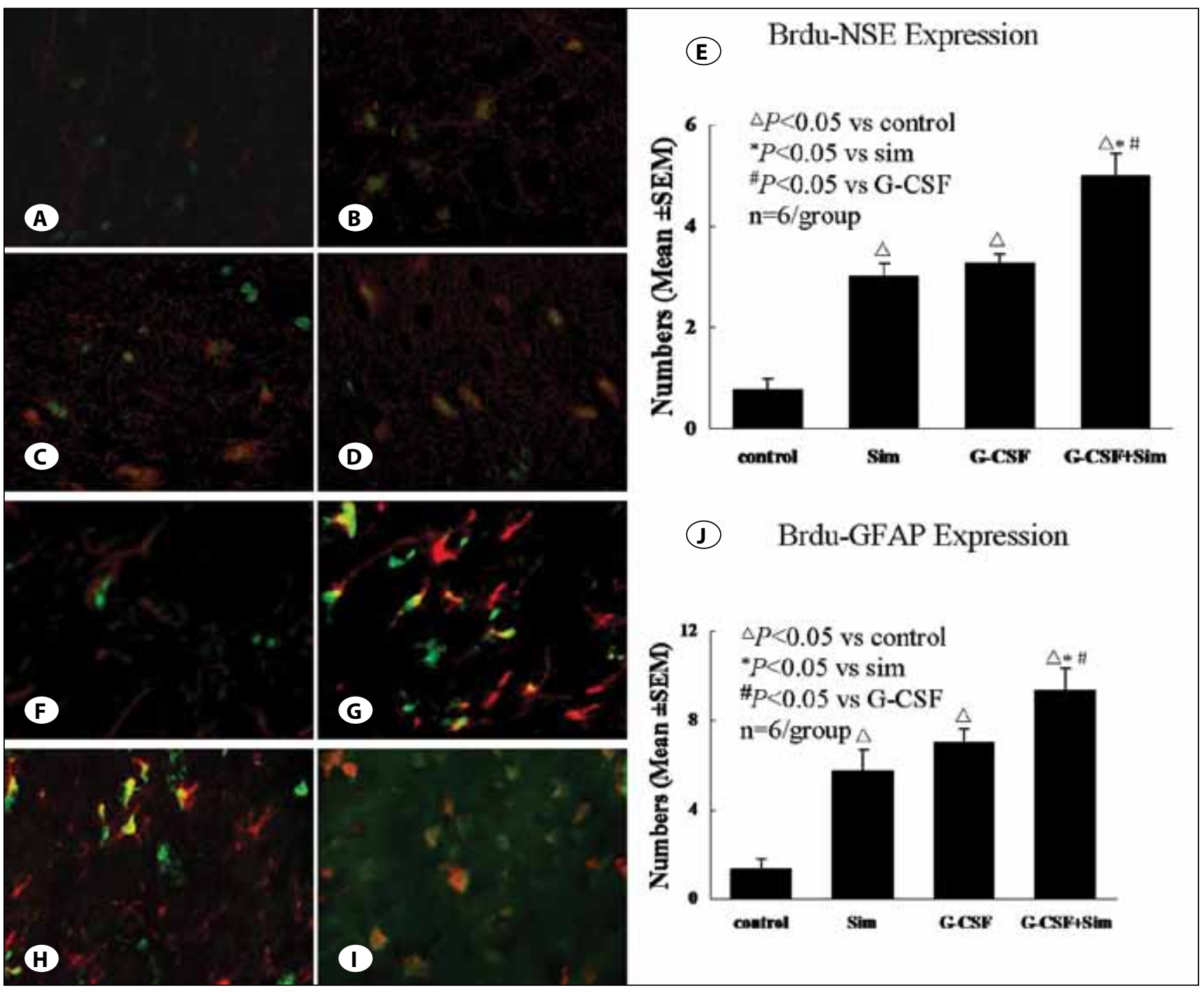

Figure 3: Representative immunostaining and quantitative immunoreactivities of Brdu- NSE, Brdu- GFAP near injured area. A-D) Colocalization of BrdU and NSE (A) control group; (B) G-CSF; (C) Simvastatin; (D) combination treatment). F-I) Colocalization of BrdU and GFAP (F) control group; (G) G-CSF; (H)Simvastatin; (I) combination treatment). Quantitative immunoreactivities for all four groups are presented as bar graphs $(\mathbf{E}, \mathbf{J})$.

indicated that combined therapy G-CSF with Simvastatin promoted significantly the proliferation of microvessels around the injured region.

\section{Cell apoptosis in the Hemorrhagic Brains}

Apoptotic cell death is another indicator of hemorrhagic damage, which was initiated shortly after ICH (data not shown). TUNEL assay (Figure 5A-E) showed that the number of TUNEL positive nuclei around the injured site substantially reduced in combination treatment than that in treated groups, remarkably decreased in the G-CSF and Simvastatin group than the control group. Overall, these data indicated that there was less apoptosis in rats post-ICH treated with G-CSF plus Simvastatin at 2 weeks.

\section{DISCUSSION}

During intracerebral hemorrhage $(\mathrm{ICH})$, the primary damage attributed to rapid accumulation of blood within brain parenchyma is the result of mechanical damage associated with the mass effect. Then the resulting local blood clot triggers a series of adverse events that cause secondary insults, which lead to normal ultrastructural neuro-disruption, midline shift, deadly edema formation, oxidative stress and inflammation. Ultimately, these elicit severe neurological deficits. The pathophysiological features occurring after spontaneous $\mathrm{ICH}$ could be well understood depending on experimental ICH animal model induced by direct injection of autologous blood into the striatum of the rat that has been proven to be reliable for replicating the human condition. 


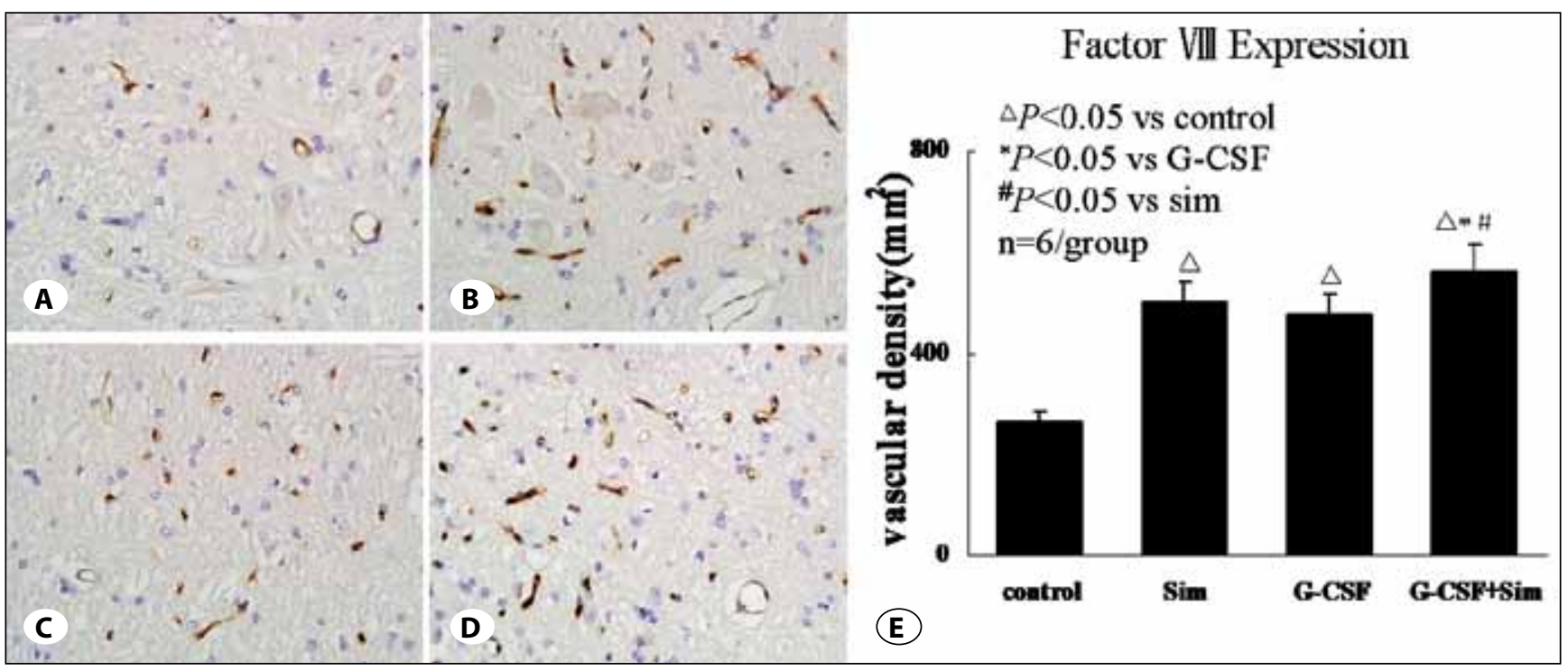

Figure 4: Representative immunostaining and quantitative immunoreactivities of microvessels with the factor VIII in the ICH border zone. A) control group; B) G-CSF; C) Simvastatin; D) combination treatment. E) Bar graphs present vascular density of the four groups in the ICH border zone.



Figure 5: Representative photomicrographs and quantitative immunoreactivities of TUNEL-positive cells in the boundary zone around the hematoma. A) control group; B) G-CSF; C) Simvastatin; D) combination treatment. E) Bar graphs present numbers of TUNEL positive cells of the four groups.

In our present study of the autologous blood induced ICH rat model, the data showed the potential therapeutic efficacy of G-CSF and simvastatin administration for neurological function recovery and regeneration. Furthermore, the most important finding in our current investigation was that the combined therapy of G-CSF and simvastatin exerted noticeably synergistic effects on histological and neurological outcomes, which significantly correlated with protecting ultrastructural damage, the new cell formation of neural cell and vascular endothelial cell, and reducing perihematomal cell death in $\mathrm{ICH}$ animals. Motor and sensory score also improved more and faster for the combination therapy of G-CSF and simvastatin than either therapy alone. These findings suggest that simvastatin administration facilitates the efficacy of G-CSF by attenuating neurological deficits and improving motor and sensory function which in parallel with the improved histological outcome in this ICH model.

Similar results were observed when both G-CSF and simvastatin exhibited a beneficial modulatory effect on morphological recovery. According to our assessment on 
brain slices, with the use of electron microscope, the degree of neuronal ultrastructural damage was evaluated by obvious perinuclear edema, mitochondrial swelling and destruction of synaptic structures. However, within 1 week time our present investigation observed pronounced recovery of these damaged organelles for the sole administration of G-CSF and simvastatin, especially for the G-CSF and simvastatin co-treatment group. The combination treatment did elicit a neuroprotective effect, especially on the higher intraneuronal vacuoles $\mathrm{Vv}$. The results showed that combination therapy group with G-CSF and simvastatin was superior to either one alone in increasing synaptic vesicles density in the boundary zone around the hematoma. It appears that synaptic vesicles play critical role in regulating synaptic reorganization (6). Besides, the combined treatment group had significant neurological improvement from 1 week post-ICH onward. Therefore, our findings proved that G-CSF therapy offered similar protection of ultrastructural structure compared with simvastatin therapy. Of importance is that co-treatment group markedly improved histomorphological outcome which may contribute to functional outcome.

A series of previous studies indicated that G-CSF, the prototypical mobilizing agents, have the capability of mobilizing and proliferating bone marrow-derived stem cells (BMSC) composed of hematopoietic progenitor cells and bone marrow stromal cells from bone marrow into peripheral blood (5). It is important to note that stromal-derived factor-1 (SDF-1), the stem cell homing factor, regulated the migration or homing of BMSC in the circulation to the lesion site of the central nervous system (4). Of course, there may be other detailed molecular mechanisms involved in this process, which is currently not fully elucidated. Anyhow, G-CSF facilitates potential neuronal and vascular endothelial proliferation thus plays a key role in potentiating intrinsic neural selfrepair processes in injured brain, which has been supported by previous findings $(11,14)$. On the other hand, apart from the lipid-lowering effects, recent studies have showed that statins possess multiple benefits on the nervous and vascular systems, such as pro-angiogenic properties and neurogenesis after stroke (8). Our experimental results demonstrated that both administration G-CSF and simvastatin increased number of BrdU and cell-specific markers co-labeled cells around the area of hemorrhage hemisphere compared to control. In addition to the increased new neurons and astrocytes formation, each monotherapy also promoted the expression of endogenous neural stem cells after $\mathrm{ICH}$. In this study, we demonstrated that combination of G-CSF and simvastatin treatment strongly induced advanced benefits on greater newly formed cells in rats after $\mathrm{ICH}$, suggesting that cell proliferation potential of G-CSF influence on central nervous system was enhanced by simvastatin administration. Also, many studies including our present work have shown that both G-CSF and simvastatin significantly enhanced the microvasculature densities in vivo. The impact of G-CSF on promoting angiogenesis was notably enhanced when treated with simvastatin. The mechanism of angiogenesis for simvastatin may relate to the fact that endothelial NO synthase (eNOS)/vascular endothelial growth factor (VEGF) mediated signal transduction play important role in improvement of the endothelial function from previous reports (18).

Furthermore, like the anti-apoptotic effect ofG-CSF, simvastatin has been known to have the equal biological features, which have been consisted with our observation in the TUNEL assay. G-CSF was found to exert a direct effect on attenuating cells death through the G-CSF receptors expressed on neurons and glial cells by triggering downstream signaling pathway. It is suggested that G-CSF and granulocyte-macrophage colony-stimulating factor (GM-CSF) induced activation of the activator of transcription (STAT) signaling pathways and the apoptosis regulation factors $(3,16)$. Likewise, simvastatinmediated anti-apoptotic effect could via upregulation of the anti-apoptotic molecule B-cell lymphoma 2 (Bcl-2) (9). Accordingly, the apoptosis cells in the boundary zone around the hematoma were significantly reduced after combined treatment of G-CSF and simvastatin than either therapy alone as evidenced by our present study.

\section{CONCLUSIONS}

Our data show that the administration of G-CSF together with simvastatin is superior to either therapy alone in enhancing histological and neurological outcomes in experimental $\mathrm{ICH}$. It appears that the mechanism underlying the therapeutic efficacy of the combination therapy may be linked to the amelioration of ultrastructural structure, promotion of neurogenesis and neovascularization, and reduction of the number of apoptosis.

\section{ACKNOWLEDGMENTS}

This work was supported by Plan For Scientific Innovation Talent of Henan Province.

\section{REFERENCES}

1. Anik I, Secer HI, Anik Y, Duz B, Gonul E: Meta-analyses of intracerebral hematoma treatment. Turk Neurosurg 21(1): 6-14, 2011

2. Chen J, Li Y, Wang L, Zhang Z, Lu D, Lu M, Chopp M: Therapeutic benefit of intravenous administration of bone marrow stromal cells after cerebral ischemia in rats. Stroke 32: 1005- 1011, 2001

3. Choi JK, Kim KH, Park H, Park SR, Choi BH: Granulocyte macrophage-colony stimulating factor shows anti-apoptotic activity in neural progenitor cells via JAK/STAT5-BCl-2 pathway. Apoptosis 16:127-134, 2011

4. Cui $X$, Chen J, Zacharek A: Nitric oxide donor upregulation of stromal cell-derived factor-1/chemokine (CXC motif) receptor 4 enhances bone marrow stromal cell migration into ischemic brain after stroke. Stem Cells 25:2777-2785, 2007

5. Deng J, Zou ZM, Zhou TL, Su YP, Ai GP, Wang JP, Xu H, Dong SW: Bone marrow mesenchymal stem cells can be mobilized into peripheral blood by G-CSF in vivo and integrate into traumatically injured cerebral tissue. Neurol Sci 32:641-651, 2011 
6. Dietrich MO, Andrews ZB, Horvath TL: Exercise-induced synaptogenesis in the hippocampus is dependent on UCP2-regulated mitochondrial adaptation. J Neurosci 28: $10766-10771,2008$

7. Jasińska M, Owczarek J, Orszulak-Michalak D: Statins: A new insight into their mechanisms of action and consequent pleiotropic effects. Pharmacol Rep 59:483-499, 2007

8. Karki K, Knight RA, Han Y, Yang D, Zhang J, Ledbetter KA, Chopp M, Seyfried DM: Simvastatin and atorvastatin improve neurological outcome after experimental intracerebral hemorrhage. Stroke 40:3384-3389, 2009

9. Ko $M L$, Chen $C F$, Peng $\mathrm{PH}$, Peng $\mathrm{YH}$ : Simvastatin upregulates $\mathrm{BCl}-2$ expression and protects retinal neurons from early ischemia/reperfusion injury in the rat retina. Exp Eye Res 93:580-585, 2011

10. Martins AJ, Spanton S, Sheikh HI, Kim SO: The antiinflammatory role of granulocyte colony-stimulating factor in macrophage-dendritic cell crosstalk after Lactobacillus rhamnosus GR-1 exposure. J Leukoc Biol 89:907-915, 2011

11. Park HK, Chu K, Lee ST, Jung KH, Kim EH, Lee KB, Song YM, Jeong SW, Kim M, Roh JK: Granulocyte colony-stimulating factor induces sensorimotor recovery in intracerebral hemorrhage. Brain Res 1041:125-131, 2005

12. Qureshi Al, Tuhrim S, Broderick JP: Spontaneous intracerebral hemorrhage. N Engl J Med 344:1450-1460, 2001

13. Sanli AM, Serbes G, Caliskan M, Kaptanoglu E, Sargon MF, Kilinc K, Besalti O, Sekerci Z: Effect of granulocyte-colony stimulating factor on spinal cord tissue after experimental contusion injury. J Clin Neurosci 17:1548-1552, 2010
14. Sehara $Y$, Hayashi T, Deguchi K, Zhang H, Tsuchiya A, Yamashita T, Lukic V, Nagai M, Kamiya T, Abe K: Potentiation of neurogenesis and angiogenesis by G-CSF after focal cerebral ischemia in rats. Brain Res 1058:120-128, 2005

15. Seyfried D, Ding J, Han Y, Li Y, Chen J, Chopp M: Effects of intravenous administration of human bone marrow stromal cells after intracerebral hemorrhage in rats. J Neurosurg 104: 313-318, 2006

16. Solaroglu I, Tsubokawa T, Cahill J, Zhang JH: Anti-apoptotic effect of granulocyte-colony stimulating factor after focal cerebral ischemia in the rat. Neuroscience 143:965-974, 2006

17. Tamura M, Hattori $K$, Nomura $H$, Oheda M, Kubota N, Imazeki I, Ono M, Ueyama Y, Nagata S, Shirafuji N: Induction of neutrophilic granulocytosis in mice by administration of purified human native granulocyte colony-stimulating factor (G-CSF). Biochem Biophys Res Commun 142:454-460, 1987

18. Wu H, Lu D, Jiang H, Xiong Y, Qu C, Li B, Mahmood A, Zhou $D$, Chopp M: Simvastatin-mediated upregulation of VEGF and BDNF, activation of the PI3K/Akt pathway, and increase of neurogenesis are associated with therapeutic improvement after traumatic brain injury. J Neurotrauma 25:130-139, 2008

19. Xu J, Liu X, Chen J, Zacharek A, Cui X, Savant-Bhonsale S, Liu $Z$, Chopp M: Simvastatin enhances bone marrow stromal cell differentiation into endothelial cells via notch signaling pathway. Am J Physiol Cell Physiol 296:C535-543, 2009

20. Zhang L, Schallert T, Zhang ZG, Jiang Q, Arniego P, Li Q, Lu M, Chopp M: A test for detecting long-term sensorimotor dysfunction in the mouse after focal cerebral ischemia. J Neurosci Methods 117: 207-214, 2002 